\title{
Cap Device
}

National Cancer Institute

\section{Source}

National Cancer Institute. Cap Device. NCI Thesaurus. Code C49861.

A top (as for a bottle). 